DOI

\title{
ФУНКЦІОНАЛЬНИЙ СТАН ПЕЧІНКИ У ХВОРИХ ІЗ КОМОРБІДНИМ ПЕРЕБІГОМ ОСТЕОАРТРОЗУ ТА ОЖИРІННЯ ЗАЛЕЖНО ВІД ПРИЗНАЧЕНОГО НЕСТЕРОЇДНОГО ПРОТИЗАПАЛЬНОГО ПРЕПАРАТУ
}

\author{
๑О. С. Хухліна, О. Д. Ляхович, Л. В. Каньовська, О. С. Воєвідка \\ Вищий державний навчальний заклад України «Буковинський державний медичний університет», \\ м. Чернівці
}

РЕЗЮМЕ. 3 метою з'ясування особливостей ураження печінки у хворих на остеоартроз та ожиріння на тлі призначення нестероїдних протизапальних засобів (НСПЗ) (німесулід, мелоксикам, диклофенак, парацетамол, ібупрофен) обстежено 48 пацієнтів з ОА колінних та кульшових суглобів із ожирінням І-ІІІ ступенів. Встановлено, що максимальний гепатотоксичний вплив при призначенні упродовж 2 тижнів хворим на ОА на тлі ожиріння мали парацетамол, диклофенак, німесулід, ібупрофен, а мінімальний - мелоксикам, який $є$ рекомендованим до призначення за даної форми коморбідності.

КЛЮчОВІ СЛОВА: остеоартроз, ожиріння, НПЗП.

Вступ. Серед ревматичних захворювань остеартроз (ОА) займає перше місце, а за поширеністю у країнах Європи знаходиться на другому місці після ішемічної хвороби серця та цереброваскулярних захворювань. За даними популяційних досліджень, його поширеність становить від 4,2 до 22,6 \% [2, 3]. Актуальною проблемою в Україні та у світі сьогодні $\epsilon$ поєднання ожиріння та ОА великих суглобів, які $\epsilon$ взаємообтяжуючими захворюваннями [3]. Призначення нестероїдних протизапальних засобів (НСПЗ) з метою лікування реактивного синовіту (PC) іноді $\epsilon$ тривалим $[1,4,5,7]$. Однак воно, крім сприяння розвитку нестероїдної гастропатії, негативного впливу на мікроциркуляцію та функціональний стан нирок, має ймовірний гепатотоксичний ефект $[6,8,9]$.

Метою дослідження було з'ясування клінічних особливостей ураження печінки на тлі остеоартрозу та ожиріння залежно від призначеного НПЗП.

Матеріал і методи дослідження. Під спостереженням перебували 48 хворих на ОА колінних суглобів, серед них 21 (43,75\%) жінка і 27 (56,25\%) чоловіків. Тривалість захворювання з моменту появи перших симптомів коливалася від 1 до 20 років (у середньому $(6,8 \pm 3,7)$ років). Вік хворих становив від 51 до 78 років. Контрольну групу для порівняння досліджень склали 24 здорових особи (30), серед яких було 12 (50\%) чоловіків та 12 (50\%) жінок, серед яких 4 особи (16,7\%) у віці 4550 років та 20 осіб (83,3\%) у віці 51-78 років.

Дослідження проведені при поступленні пацієнтів та після двох тижнів їх перебування в стаціонарі. 1372 обстежених осі6 12 хворихмали надмірну масутіла, 12 хворих-1 ст. ожиріння, 12 хворих -2 ст. ожиріння, 12 хворих -3 ст.ожиріння, 24 особи - 30 із нормальною масою тіла. У свою чергу, кожна із 4 груп хворих із підвищеною масою тіла була поді- лена навпіл. Перша половина пацієнтів приймали селективні інгібітори циклооксигенази-2 (ЦОГ-2): мелоксикам і німесулід - по 12 (25 \%) пацієнтів; друга половина пацієнтів приймали неселективні інгібітори ЦОГ-2: ібупрофен, диклофенак і парацетамол - по 8 (16,7 \%) пацієнтів. Критеріями включення у дослідження були підписана пацієнтом інформована згода, інтенсивність болю у так званих цільових суглобах > 40 мм за візуальною аналоговою шкалою (ВАШ), відсутність в анамнезі вказівок на непереносимість досліджуваних препаратів. Критеріями виключення хворих з дослідження були ОА колінних та кульшових суглобів IV рентгенологічної стадії, неконтрольована артеріальна гіпертензія II-III ст., захворювання печінки (вірусної, автоімунної, токсичної, алкогольної природи) і нирок; ішемічна хвороба серця із СН IIA - III Ст., церебральний інсульт, цукровий діабет, виразкова хвороба шлунка та/або дванадцятипалої кишки в стадії загострення, бронхіальна астма та ХОЗЛ.

Діагноз ОА встановлювали на основі діагностичних критеріїв ACR (1990) (Коваленко В. Н., Шуба Н. М. (ред.), 2004). Ожиріння діагностували


Усім пацієнтам був проведений повний комплекс об'єктивного обстеження, клініко-лабораторних та інструментальних методів дослідження. Лабораторне обстеження пацієнтів включало клінічні аналізи крові та сечі, показники системи згортання, біохімічні дослідження крові: рівень загального білка, білірубін і його фракції, активність аспартатамінотрансферази (АСАТ), аланінамінотрансферази (АлАТ), гама-глутамілтрансферази (ГГТ), лужної фосфатази (ЛФ), тимолова проба.

Статистичну обробку результатів дослідження проводили у наступному порядку. Первинні дані обстеження хворих на ОА та підвищену масу тіла були внесені у розроблену нами базу даних. 
Огляди літератури, оригінальні дослідження, погляд на проблему

База даних створена нами для уніфікації вводу, зберігання та обчислення даних з вивчення стану хворих на основі програмної оболонки Microsoft Excel (®Microsoft Corp., 1992-2-14).

Статистичний аналіз проводили з використанням програми SPSS Statistics 20 Multilingual. Результати у вигляді таблиць та діаграм переводили у базу даних. У процесі статистичної обробки результатів дослідження визначали тип розподілу даних, дескриптивні показники, вірогідність отриманих результатів та інші види аналізу. Тип розподілу даних визначали за порівнянням середньої арифметичної, моди та медіани (центральної тенденції), скошеності вибірки та аналізом гістограм розподілу даних. Для даних, що відповідали нормальному розподілу, визначали середню арифметичну вибірку (М), величину стандартного відхилення (s) та стандартної похибки (m), максимальне та мінімальне значення. Вірогідності різниці між отриманими даними оцінювали за коефіцієнтом Стьюдента (t). За вірогідну приймали різницю при $p<0,05$. Для даних з іншими типами розподілу користувалися непараметричними статистичними методами. При цьому вірогідність різниці визначали за критеріями Фішера, кореляційний аналіз проводили за ранговою кореляцією за критеріями Спірмена та Пірсона.

Результати й обговорення. Першим етапом дослідження було визначення функціонального стану печінки до призначення НСПЗ препаратів.
У клінічній практиці, крім прямих значень маркерів цитолізу: активності АсАТ і АлАТ, часто використовується їх співвідношення АсАТ/АлАТ, яке отримало назву коефіцієнта де Рітіса. Середня активність маркерів цитолізу до лікування у хворих на ОА на тлі ожиріння дещо перевищувала показник у 30: АсАт - у 1,3 раза $(p<0,05)$, АлАТ - у 1,9 раза $(p<0,05)$. Водночас показники коефіцієнта де Рітіса становили менше $1(p<0,05)$, що було у $1,5$ раза нижче за показник у $30(p<0,05)$ (табл. 1$)$. Цей факт вказує на початкові ознаки м'якого неалкогольного стеатогепатиту (НАСГ) на тлі коморбідного ожиріння.

Як свідчать отримані дані (табл. 1), було виявлено також зростання активності ГГТ у середньому в 1,4 раза $(p<0,05)$ паралельно із зростанням активності ЛФ у 1,6 раза $(p<0,05)$ і у міжгруповому аспекті вірогідності змін встановлено не було $(p>0,05)$. Цей факт вказує на розвиток холестазу нетоксичного ґенезу внаслідок формування м'якого НАСГ внаслідок коморбідного ожиріння.

Аналіз показників тимолової проби до призначення НСПЗ, згідно з даними таблиці 1, вказує на те, що у всіх групах хворих активність мезенхімального запалення була вірогідно підвищеною, порівняно з 30, у 1,3 раза $(p<0,05)$. Цей факт можна пояснити як гіперпродукцією та дисбалансом адипоцитокінів на тлі ожиріння із переважанням гормонів прозапальної дії, так і наявністю реактивного синовіту на тлі ОА.

Таблиця 1. Показники активності маркерів цитолізу (АсАТ, АлАТ) та холестазу (ГГТ, ЛФ),

мезенхімально-запального процесу (тимолова проба) у хворих на остеоартроз із реактивним синовітом до призначення НПЗП та парацетамолу

\begin{tabular}{|l|c|c|c|c|c|c|}
\hline \multirow{2}{*}{$\begin{array}{c}\text { Показник одиниці } \\
\text { вимірювання }\end{array}$} & $\begin{array}{c}\text { 3дорові осо- } \\
\text { би (група 1) } \\
\mathrm{n=24}\end{array}$ & $\begin{array}{c}\text { мелоксикам } \\
\text { (група 2) } \\
\mathrm{n}=12\end{array}$ & $\begin{array}{c}\text { німесулід } \\
\text { (група 3) } \\
\mathrm{n}=12\end{array}$ & $\begin{array}{c}\text { iбупрофен } \\
\text { (група 4) } \\
\mathrm{n}=8\end{array}$ & $\begin{array}{c}\text { диклофенак } \\
\text { (група 5) } \\
\mathrm{n}=8\end{array}$ & $\begin{array}{c}\text { парацетамол } \\
\text { (група 6) } \\
\mathrm{n}=8\end{array}$ \\
\hline АсАТ, ммоль/ год хл & $0,49 \pm 0,012$ & $0,49 \pm 0,08$ & $0,67 \pm 0,02^{*}$ & $0,62 \pm 0,02^{*}$ & $0,70 \pm 0,02^{*}$ & $0,72 \pm 0,01^{*}$ \\
\hline АлАТ, ммоль/ год х л & $0,38 \pm 0,018$ & $0,72 \pm 0,01^{*}$ & $0,74 \pm 0,01^{*}$ & $0,73 \pm 0,01^{*}$ & $0,76 \pm 0,01^{*}$ & $0,77 \pm 0,01^{*}$ \\
\hline Коефіцієнт де Рітіса & $1,29 \pm 0,01$ & $0,68 \pm 0,03^{*}$ & $0,90 \pm 0,02^{*}$ & $0,85 \pm 0,02^{*}$ & $0,9 \pm 0,02^{*}$ & $0,94 \pm 0,01^{*}$ \\
\hline ГГТ, ммоль/год хл & $4,12 \pm 0,29$ & $5,67 \pm 0,40^{*}$ & $5,72 \pm 0,43^{*}$ & $5,92 \pm 0,51^{*}$ & $5,9 \pm 0,52^{*}$ & $5,56 \pm 0,53^{*}$ \\
\hline ЛФ, ммоль/год хл & $0,92 \pm 0,04$ & $1,33 \pm 0,03^{*}$ & $1,55 \pm 0,05^{*}$ & $1,52 \pm 0,05^{*}$ & $1,52 \pm 0,08^{*}$ & $1,61 \pm 0,09^{*}$ \\
\hline Тимолова проба, ОД. & $3,97 \pm 0,09$ & $5,06 \pm 0,04^{*}$ & $5,34 \pm 0,22^{*}$ & $5,28 \pm 0,05^{*}$ & $5,56 \pm 0,05^{*}$ & $5,61 \pm 0,06^{*}$ \\
\hline
\end{tabular}

Примітка: * - різниця показників вірогідна $(p<0,05)$ із групою практично здорових осіб.

Оскільки ще до призначення терапії НСПЗ ми засвідчили наявність цитолітичного синдрому м'якої активності (підвищена активність АсАТ, АлАТ та знижений коефіцієнт де Рітіса), синдрому холестазу (підвищені показники активності ГГТ та ЛФ), мезенхімально-запального синдрому (підвищені показники тимолової проби), можемо зробити висновок про наявність неалкогольного стеатозу печінки, що було підтверджено наявністю дорзального згасання ультрасонографічного сигналу при УЗД печінки, а також НАСГ м'якої активності, викликаними, швидше за все, наявним у пацієнтів ожирінням.

Аналіз маркерів цитолітичного синдрому в динаміці призначення НСПЗ показав (табл. 2), що активність АлАТ зросла у хворих всіх груп у серед- 
Огляди літератури, оригінальні дослідження, погляд на проблему

ньому в 1,3-1,4 раза ( $<<0,05)$, за винятком 2-ї групи (p>0,05), де зміни, порівняно з показником до лікування, були невірогідні. Активність АсАт зросла більш суттєво: у хворих з 3 по 5 групи - у 2,0 рази $(p<0,05)$, у хворих 6 групи - у 2,2 раза $(p<0,05)$, водночас, у хворих 2 групи не змінилася $(p>0,05)$. При порівнянні показників коефіцієнта де Рітіса у групах після лікування (табл. 2) виявлено вірогідне зростання показників: у хворих 2 групи коефіцієнт зріс у 1,2 раза (р<0,05), а у групах 4 та 5 - зріс приблизно в 1,5 раза $(p<0,05)$, причому максимальні його значення були встановлені у третій та шостій групах $((1,43 \pm 0,05)$ та $(1,52 \pm 0,02)-$ зростання в $1,6$ раза $(p<0,05))$. Отримані результати вказують на прямі ознаки токсичних, медикаментозно індукованих впливів на печінку.

Таблиця 2. Динаміка активності маркерів цитолізу (АсАТ, АлАТ) та холестазу (ГГТ, ЛФ), мезенхімально-запального процесу (тимолова проба), у хворих на остеоартроз із реактивним синовітом після призначення НПЗП та парацетамолу

\begin{tabular}{|c|c|c|c|c|c|c|}
\hline \multirow[b]{2}{*}{$\begin{array}{c}\text { Показники, одиниці } \\
\text { вимірювання }\end{array}$} & \multirow{2}{*}{$\begin{array}{c}\text { Практично } \\
\text { здорові } \\
\text { (група 1) } \\
\text { n=24 }\end{array}$} & \multicolumn{5}{|c|}{ Групи обстежених хворих } \\
\hline & & $\begin{array}{c}\text { мелоксикам } \\
\text { (група 2) } \\
\mathrm{n}=12\end{array}$ & $\begin{array}{c}\text { німесулід } \\
\text { (група 3) } \\
n=12\end{array}$ & $\begin{array}{c}\text { ібупрофен } \\
\text { (група 4) } \\
\text { n=8 }\end{array}$ & $\begin{array}{c}\text { диклофенак } \\
\text { (група 5) } \\
\mathrm{n}=8\end{array}$ & $\begin{array}{c}\text { парацетамол } \\
\text { (група 6) } \\
\mathrm{n}=8\end{array}$ \\
\hline АСТ, ммоль/год х л & $0,49 \pm 0,012$ & $0,52 \pm 0,07$ & $1,40 \pm 0,06 * / * *$ & $1,26 \pm 0,05 * / * *$ & $1,37 \pm 0,07 * / * *$ & $1,57 \pm 0,09 * / * *$ \\
\hline АЛТ, ммоль/год х л & $0,38 \pm 0,018$ & $0,72 \pm 0,01^{*}$ & $0,98 \pm 0,03 * / * *$ & $1,01 \pm 0,03 * / * *$ & $1,02 \pm 0,05 * / * *$ & $1,03 \pm 0,06 * / * *$ \\
\hline Коефіцієнт & $1,29 \pm 0,010$ & $0,82 \pm 0,01 * / * *$ & $1,43 \pm 0,05 * / * *$ & $1,25 \pm 0$ & $1,34 \pm 0$, & $1,52 \pm 0,02 * / * *$ \\
\hline ГГТ, ммоль /год х л & $4,12 \pm 0,29$ & $6,06 \pm 0,43^{*}$ & $6,21 \pm 0,44^{*}$ & $6,41 \pm 0,54^{*}$ & $6,50 \pm 0,56^{*}$ & $7,85 \pm 0,57 * / * *$ \\
\hline ЛФ, ммоль /год х л & $0,92 \pm 0,04$ & $1,41 \pm 0,03 *$ & $2,03 \pm 0,12 * / * *$ & $1,89 \pm 0,06 * / * *$ & $1,92 \pm 0,12 * / * *$ & $2,04 \pm 0,13 * / * *$ \\
\hline Тимолова проба, од. & $3,97 \pm 0,09$ & $5,13 \pm 0,07^{*}$ & $6,58 \pm 0,05 * / * *$ & $5,68 \pm 0,05 * / * *$ & $6,10 \pm 0,06 * / * *$ & $7,19 \pm 0,05 * / * *$ \\
\hline
\end{tabular}

Примітки: * - різниця показників вірогідна $(p<0,05)$ із групою практично здорових осіб; ** - різниця показників вірогідна (р<0,05) між аналогічною групою до лікування НПЗП.

У всіх групах спостереження була зареєстрована тенденція до зростання активності ГГТ (р>0,05). Як свідчать отримані дані (табл. 2), максимальне вірогідне зростання активності ГГТ було зареєстроване у групі $6(p<0,05)$. Водночас, під впливом НСПЗ вірогідно зростала активність ЛФ у межах 1,2-1,3 раза $(p<0,05)$ у всіх групах, за винятком другої ( $p>0,05)$, що свідчить про здатність НСПЗ викликати холестаз.

Показники тимолової проби після призначення НСЗП, згідно з даними таблиці 2, змінювалися таким чином, що у всіх групах хворих активність була підвищеною порівняно зі $30(p<0,05)$ i у хворих 3-6 груп зростала у зв'язку з вживанням НАП3: у 4-5 групах - у межах 8-10\% $(p<0,05)$, у 3 та 6 групах - у межах 20-30\% $(p<0,05)$. Зміни у 2-й групі були невірогідні ( $>>0,05)$.

Отже, динаміку активності маркерів цитолізу (АсАТ, АлАТ) тахолестазу (ГГТ, ЛФ), мезенхімальнозапального процесу (тимолова проба), у хворих на остеоартроз із реактивним синовітом до та після призначення терапії НПЗП та парацетамолом упродовж 14 днів можна описати наступним чином (див. табл. 1 та 2): у групі хворих, які отримували мелоксикам, показники активності АсАТ та АлАТ не змінилися, дещо знизився коефіцієнт де Рітіса (р<0,05), зміни ГГТ, ЛФ та тимолової проби були невірогідні (p>0,05); у групі німесуліду, ібупрофену, диклофенаку маркери цитолізу та кое- фіцієнта де Рітіса вірогідно зросли $(p<0,05)$, також зросла інтенсивність холестазу та мезенхімального запалення ( $<<0,05)$; максимальним проявом гепатотоксичності характеризувався парацетамол, оскільки усі показники функціональних проб печінки при його застосуванні зросли вірогідно і максимально $(p<0,05)$.

Зазначений факт свідчить про те, що у більшості пацієнтів з остеоартрозом, які тривало вживали НПЗП, за винятком мелоксикаму, наявні явища медикаментозно індукованого цитолізу гепатоцитів, помірно вираженого холестазу та мезенхімального запалення, що дає підстави встановити діагноз медикаментозного гепатиту, активність якого максимальна у групі хворих, які отримували парацетамол $(p<0,05)$.

Висновок. За умов розвитку реактивного синовіту у хворих на ОА та ожиріння на тлі призначення НПЗП упродовж двох тижнів виникли класичні симптоми медикаментозно індукованого гепатиту із зростанням активності амінотрансфераз: АсАТ у межах 2,0-2,2 раза $(p<0,05)$, АлАТ 1,3-1,4 раза ( $p<0,05)$; із зростанням коефіцієнта де Рітіса в межах 1,2-1,6 раза ( $p<0,05)$, явищ холестазу, мезенхімального запалення, системних токсичних впливів $(p<0,05)$. Максимальний токсичний вплив на функціональний стан печінки у порядку зростання інтенсивності впливу на маркери цитолітичного синдрому чинили наступні 
Огляди літератури, оригінальні дослідження, погляд на проблему

препарати: ібупрофен, диклофенак, німесулід, парацетамол $(p<0,05)$. Мелоксикам гепатотоксичного впливу не чинив $(p>0,05)$. Отже, за даної форми коморбідності мелоксикам $\epsilon$ рекомендованим до призначення.
Перспективою подальших досліджень у цьому напрямку $\epsilon$ дослідження варіантів медикаментозно індукованих гепатитів (гепатоцелюлярного, холестатичного, змішаного) при дослідженні більшої кількості хворих із коморбідним перебігом остеоартрозу та ожиріння.

\section{ЛІТЕРАТУРА}

1. Звягинцева Т. Д. Лекарственные поражения печени. НПВП-ассоциированные гепатопатии: актуальность проблемы и современные терапевтические подходы / Т. Д. Звягинцева., А. И. Чернобай // Укр. мед. часопис. 2014. - № 1 (99). - С. 80-85.

2. Коваленко В. М. Остеоартроз і біль: стан проблеми / В. М. Коваленко, О. П. Борткевич // Боль. Суставы. Позвоночник. - 2011. - № 1. - С. 41-44.

3. Сміян С. І. Оцінка ефективності лікування остеоартрозу у пацієнтів з надмірною масою тіла і метаболічним синдромом / С. І. Сміян, С. Р. Гусак // Внутрішня медицина. - 2008. - № 4 (10). - С. 49-54.

4.Хухліна О. С. Неалкогольна жирова хвороба печінки, метаболічний синдром і синдром надмірного бактеріального росту: клінічні особливості перебігу, патогенетичні механізми взаємообтяження та підходи до лікування / О. С. Хухліна, І. Ю. Корнійчук, О. Є. Мандрик. - Чернівці, 2013. -245 с.
5. Хухліна О. С. Неалкогольний стеатогепатит та гіпертонічна хвороба: особливості коморбідного перебігу, оптимізовані підходи до лікування / О. С. Хухліна, О. Є. Мандрик - Чернівці, 2014. - 204 с.

6. Шуба Н. М. Гепатотоксичность НПВП: существует ли реальная угроза? / Н. М. Шуба, Т. Д. Воронова // Укр. ревматол. журн. - 2009. - № 1 (35). - С. 33-39.

7. Aithal G. P. Case definition and phenotype standardization in drug-induced liver injury / G. P. Aithal, P. B. Watkins, R. J. Andrade [et al.] // Clin. Pharmacol. Ther.2011. - № 89 (6). - P. 806-815.

8. Bell L. N. Epidemiology of idiosyncratic drug-induced liver injury / L. N. Bell, N. Chalasani // Semin. Liver Dis. - 2009. - № 29 (4). - P. 337-347.

9. Mengoli M. Drug-induced hepatotoxicity: clinical and biochemical features of 26 patients and a review of the literature / M. Mengoli, D. Parmeggiani, M. C. Mengoli [et al.] // Recenti Prog. Med. - 2011. - № 102 (6). - P. 253-260.

\section{FUNCTIONAL LIVER STATUS IN PATIENTS WITH COMORBID COURSE OF OSTEOARTHROSIS AND OBESITY DEPENDING ON THE NONSTEROIDAL ANTI-INFLAMMATORY DRUG}

\section{O. S. Khukhlina, O. D. Liakhovych, L. V. Kaniovska, O. S. Voyevidka}

Higher State Educational Establishment of Ukraine «Bukovynian State Medical University», Chernivtsi

SUMMARY. In order to clarify the peculiarities of liver lesions in patients with osteoarthrosis (OA) and obesity against the ground of nonsteroidal anti-inflammatory drugs (NSAIDs) indication (nimesulide, meloxicam, diclofenac, paracetamol, ibuprofen) 48 patients have been examined with OA of the knee and femoral joints and obesity of I-III degrees. Maximal hepatotoxic effect after 2 week administration for patients with OA and obesity has been found to be manifested in case of paracetamol, diclofenac, nimesulide, ibuprofen indications; meloxicam demonstrates a minimal hepatotoxic effect and can be recommended in case of this comorbidity.

KEY WORDS: osteoarthrosis, obesity, NSAIDs. 